\title{
Growth in first- and second-generation immigrant firms in Sweden **
}

\author{
In Press, International Small Business Journal.
}

Nedim Efendic

Stockholm School of Economics

P.O. Box 6501

SE-11383 Stockholm

Sweden

nedim.efendic@hhs.se

\author{
Fredrik W. Andersson \\ Statistics Sweden \\ Klostergatan 23 \\ SE-701 89 Örebro \\ Sweden
}

fredrik.andersson@scb.se

\author{
Karl Wennberg ** \\ Department of Management and Engineering \\ $\&$ \\ Institute for Analytical Sociology (IAS) \\ Linköping University, Sweden \\ E-mail: karl.wennberg@liu.se \\ Tel: +46-705-10 5366
}

Keywords: Immigrant entrepreneurship; intergenerational differences; firm growth, Sweden

JEL CODES: J61, M13, 018

* Corresponding author

** We are grateful for feedback from the three anonymous reviewers and the editor Susan Marlow, Andreas Bergström, Harald Edquist, Carin Holmquist, Isaac Karlsson, Anna Rehnvall, Veronique Schutjens, Thomas Schøtt, Siri Terjesen, Ivo Zander, Karin Zelano, and seminar participants at the Stockholm School of Economics and SCANCOR at Stanford University. Efendic gratefully acknowledge financial support by FORES and the Swedish Agency for Economic and Regional Growth. Wennberg gratefully acknowledge financial support by the Swedish Research Council (340-2013-5460), Riksbankens Jubileumsfond (M12-0301:1) and the Swedish Wholesale and Retail Development Council. A previous version received a 'best paper award' at the 2014 Uddevalla Symposium. All errors remain those of the authors. 


\title{
Growth in first- and second-generation immigrant firms in Sweden
}

\begin{abstract}
Despite the burgeoning literature on immigrant entrepreneurship, there is a dearth of research on the social and economic factors shaping the performance of immigrant-run firms. Drawing upon human and social capital theory and assimilation theory, we investigate differences in performance measured as revenue growth in a comparative study of native and immigrant CEOs. Following 50,002 small firms in Sweden over four years, we find distinct patterns in both firm size and revenue growth between firms managed by immigrants and by natives. While firms run by second-generation immigrants from OECD countries exhibit higher growth rates than natives, the reverse is true for second generation immigrants from non-OECD countries, suggesting that economic integration in terms of immigrants' small business growth in Sweden is characterized by segmented rather than universal assimilation.
\end{abstract}

\section{Introduction}

Immigrants in developed countries are more prone to launch small businesses than natives (Fairlie, 2012). The performance of these businesses are often portrayed as limited due to immigrants' constrained levels of human, financial, and social capital (Bates, 2011; Hjerm, 2004). However, there is little evidence regarding how such capital sources shape the performance of immigrant businesses and whether patterns differ from businesses run by natives (Aldrich and Waldinger, 1990; Bates, 1990). Most research investigating social and human capital among immigrant entrepreneurs has studied how these factors affect entrepreneurial entry rather than business growth or performance (Beckers and Blumberg, 2013; Ram and Carter, 2003). Previous research has also focused on entrepreneurs born abroad (i.e., first-generation immigrant entrepreneurs) (Light, 1979; Rusinovic, 2008), largely neglecting the large group of entrepreneurs whose parents were born abroad (i.e., secondgeneration immigrant entrepreneurs) (Ndofor and Priem, 2011). Theories of assimilation in sociology and migration research have suggested that the prospects facing second-generation 
immigrants are different from first-generation immigrants, which may have ramifications on the growth trajectory of their businesses (Portes and Zhou, 1993; Ram and Carter, 2003).

In this study, we shed light on these theoretical and empirical gaps in research on immigrant entrepreneurship by studying differences in revenue growth between small firms run by native CEOs, first-generation immigrant CEOs, and second-generation immigrant CEOs. We theorize on and empirically investigate how specific social and human capital factors affect the revenue growth of these individuals' businesses and how segmented assimilation may lead immigrants and their children from countries more similar to the host country to become socially and economically integrated more rapidly than immigrants from dissimilar countries, affecting small firm growth in differential ways.

We use matched employee-employer data to investigate all small incorporated firms in Sweden from 2005 to 2008, which provides higher generalizability than prior sample-based studies. Based on the notion that human and social capital are important for growth, our main theoretical predictor variables are CEO education, number of entrepreneurs in the family, and network connections through professional boards. Immigrant firms are considered to be firms run by first- or second-generation immigrant CEOs. The comparison groups are immigrant status (i.e., whether the CEO is a first- or second-generation immigrant, separated into immigrants from Organisation for Economic Co-Operation and Development [OECD] countries and those from non-OECD countries) with native CEOs (born in Sweden and with at least one Swedish parent) as the baseline category. We test our hypotheses using panel data and quantile regression models that seek to account for heterogeneity in growth patterns and differences in growth rates over time (Delmar, Davidsson and Gartner, 2003).

The results indicate substantial differences in revenue growth among natives and immigrants as well as differences in factors that affect fast- and slow-growing firms. Secondgeneration immigrants' firms tend to grow faster than firms run by first-generation 
immigrants or natives based on the area from which their parents emigrated. Although their average revenue level is lower, firms run by second-generation immigrant CEOs from OECD countries grow faster on average than firms run by native CEOs or first-generation immigrant CEOs. The reverse is true for firms run by second-generation immigrant CEOs from nonOECD countries, whose businesses grow slower on average than the comparison groups. Second-generation immigrants also tend to run businesses in different industry sectors (using standard industrial classification [SIC] codes) compared to first-generation immigrants, notably sectors with higher entry barriers. Taken together, our findings suggests a process of segmented assimilation where migrant groups from more economically and culturally different countries are less likely to achieve business growth in the second generation, but to some extent can overcome this disadvantage by utilizing bridging social capital resources to enhance their growth.

These findings help shed light on the puzzle of how resource-constrained immigrant-run businesses of modest size can utilize their human and social capital to achieve business growth. Our study highlights the distinct constraints faced by firms run by first- versus second-generation immigrants, with the latter group possibly being better equipped to start businesses in high-potential sectors to achieve growth.

We contribute novel results to entrepreneurship research, for which studies on immigrant entrepreneurship have mainly attended to entry patterns but rarely to growth and profitability (Aldrich and Waldinger, 1990). Our study is among the first to highlight generalizable patterns of immigrant entrepreneurship in terms of industry sector distribution, firm size, and growth rate depending on whether firms are run by natives, first-generation, or second-generation immigrants (Beckers and Blumberg, 2013). The findings provide more generality to research based on case studies or single-sector data based on surveys from a snapshot in time (Bates 2011; Jones, Ram and Theodorakopoulos, 2010). 
Overall, our paper shows that growth among immigrant entrepreneurs in Sweden is characterized by segmented rather than universal assimilation, with second-immigrant entrepreneurs from certain migrant groups, but not others, being more likely to achieve business growth (Blackburn and Ram, 2006; Hjerm, 2004).

\section{Prior research and theory development}

A common perception is that immigrant entrepreneurship is driven by a mismatch between immigrants' qualifications and available jobs—namely, entrepreneurship due to necessity (Ndofor and Priem, 2011). However, there is a dearth of studies on the actual growth of immigrants' firms. While some studies have indicated that managers' human capital (Basu and Goswami, 1999; Bates, 1994) and social capital (Renzulli and Aldrich, 2005; Ruef, 2002) may influence growth, there is a void of studies comparing the relevance of such factors for the growth of immigrant-run firms versus native-run firms (Bates, 2011). We address this gap in the literature by first providing a background to the definitions and contextual conditions surrounding immigrant entrepreneurship. Second, we theorize on the distinct conditions of first- and second-generation immigrants in terms of host country assimilation and hypothesize that second-generation immigrants will exhibit stronger growth. Third, we theorize and hypothesize on the roles of human and social capital for the growth of immigrant-run firms. Fourth, we theorize and hypothesize how first-generation immigrant entrepreneurs are segregated into various industry sectors compared to both the second generation and native entrepreneurs.

\section{Immigration and entrepreneurship}

Immigrant entrepreneurship is core to our theorizing on the role of CEOs' origin for firm growth. In small private firms, CEOs frequently occupy the roles of founder, owner, and 
operator (Fairlie, 2005). Since self-employment does not equate to entrepreneurship (Shane, 2009), we define entrepreneurs as owner-managers of firms with at least one employee in addition to the founder (Brockhaus, 1980).

Researchers use words such as immigrant entrepreneur, ethnic entrepreneur, and minority entrepreneur to characterize entrepreneurial activities by individuals not part of the majority population (Carter, Mwaura, Ram, Trehan and Jones, 2015). Immigrant entrepreneurs are commonly defined as individuals who emigrated recently and started a business often in order to earn a living (Chaganti and Greene, 2002). The reasons for starting and growing a business may differ across immigrant groups as well as between first- and second-generation immigrants. To date, research on immigrant entrepreneurship has focused on differences between immigrants and natives in the probability of becoming an entrepreneur (Andersson and Hammarstedt, 2010) and on the extent to which immigrant entrepreneurship is related to socio-economic mobility (Hjerm, 2004).

As in many developed nations (Sepulveda, Syrett and Lyon, 2011), immigration to Sweden has increased and become more diverse in terms of regions of origin (FredlundBlomst, 2014). To contextualize our research, we note that Sweden is increasingly diverse in regard to country of immigration (Welter, 2011), with a switch from predominantly labor migration from a few European countries in the 1960s to humanitarian migration from developing countries and Eastern Europe from the 1980s onward (Schierup, Hansen and Castles, 2006). Studies have shown that Swedish immigrants and their children, especially those born in non-OECD countries or with parents from non-OECD countries, often face difficulties related to socio-economic integration due to discrimination, lack of qualifications, and cultural differences between their host and home countries (Baycan-Levent and Nijkamp, 2009; Carlsson and Rooth, 2007; Rydgren, 2004). In our study we therefore differentiate between OECD (predominantly Western countries) and non-OECD (predominantly non- 
Western countries) immigrants. We also add a generational perspective to migration diversity in Sweden by examining differences between first- and second-generation immigrant entrepreneurs (Ram, Jones, Edwards, Kiselinchev, Muchenje and Woldesenbet, 2013). Next, we theorize on the distinct social and economic condition of CEOs in small firms run by either first- or second-generation immigrants and the ways gradual assimilation of immigrant entrepreneurs may impact firm growth.

\section{Segmented assimilation and growth of first- and second-generation immigrant firms}

Much of the literature on immigrant entrepreneurship has focused on businesses founded by migrants to serve specific ethnic communities. This empirical pattern is often explained by first-generation immigrant entrepreneurs not being sufficiently knowledgeable about buying preferences in the mainstream market (Rusinovic, 2008). A reason for the paucity of research on second-generation immigrant entrepreneurs is that researchers often view them as natives despite evidence that they face specific labor market constraints (Bisin, Patacchini, Verdier and Zenou, 2011; Portes and Rumbaut, 2001).

To date, there are few studies on firms run by second-generation immigrants. An exception is Beckers and Blumberg (2013), which found no distinction between first- and second-generation immigrant businesses in terms of profitability, employment growth, or survival with the exception of second-generation Chinese entrepreneurs. However, their study did not consider growth in terms of revenues, arguably the most salient measure from a business perspective (Delmar, 1997), nor did they control for firm age.

Assimilation theory explains how second-generation immigrants can better acquire the cultural capital of the host country, thereby reaching higher language proficiency and education than their parents (Farley and Alba, 2002; Portes and Rumbaut, 2001). Cultural capital in this respect means competence in the host society's culture (Bourdieu, 1986). In its 
institutionalized state, cultural capital can be represented by educational classification, while in its embodied state, it covers language proficiency and understanding of societal norms. This suggests that second-generation immigrants' better understanding of their new society positions them to be better entrepreneurs than first-generation immigrants (Portes, Guarnizo and Haller, 2002):

Hypothesis 1: Revenue growth in second-generation immigrant businesses will be higher than in first-generation immigrant businesses.

However, assimilation theory has been criticized on the grounds that assimilation in modern economies is "segmented" in that some groups of second-generation immigrants are more likely to become economically and socially integrated in the host society often through engaging in entrepreneurship (Vermeulen, 2010), whereas other groups of second-generation immigrants may be caught at the bottom of the stratification system in the host society (Zhou, 1997b). In Sweden and other European countries, this division is primarily thought to occur between immigrants from relatively developed nations, such as western and transition (OECD) nations characterized by higher education levels and more-developed economic institutions, versus immigrants from developing (non-OECD) nations characterized by lower education levels and less-developed economic institutions (Baycan-Levent and Nijkamp, 2009; Collier, 2013). Segmented assimilation thus means that some groups of secondgeneration immigrants have higher barriers to "breaking out" of the socio-economic constraints of their parents (Portes and Zhou, 1993; Ram and Carter, 2003).

While assimilation theory suggests that second-generation immigrant entrepreneurs' higher levels of integration into the host society vis-à-vis the first generation argues that these individuals are more successful as entrepreneurs, segmented assimilation theory suggests that this mechanism holds true only for certain groups of immigrants, especially those from more developed countries similar to the host country. This leads us to suggest that the chances of 
upward social mobility in terms of small business growth will be higher for OECD immigrants than for non-OECD immigrants:

Hypothesis 2: Revenue growth in businesses run by second-generation immigrants from wealthier (OECD) economies will be higher than in businesses run by second-generation immigrants from developing (non-OECD) economies.

\section{Human and social capital resources and growth of immigrant-run firms}

Immigrant entrepreneurs are often depicted as having less and different resources at their disposal compared to native entrepreneurs (Aldrich and Waldinger, 1990; Bates, 2011; Panayiotopoulos, 2006). A lack of financial and human capital is one reason for the comparatively low performance of immigrant-run firms (Bates, 1994). Human capital is often defined as an "individual's investment in personal productivity" (Light and Rosenstein, 1995, p. 122), with education and training as widely used proxies (Colombo and Grilli, 2005).

Coleman (1988) held a more sociological view, noting that human capital is created by "changes in persons that bring about skills and capabilities that make them able to act in new ways" (p. 100). From this perspective, human capital can be indirectly enhanced by individuals' social capital. For example, second-generation immigrant entrepreneurs gain skills by growing up in a host society with mandatory education, and they are likely to have contacts with both kin from their parents' generation as well as with non-migrants (Portes and Rumbaut, 2001). The general importance of human capital for performance in immigrant-run businesses (Beckers and Blumberg, 2013; Blackburn and Ram, 2006) leads us to hypothesize that CEOs' education will positively influence revenue growth in all types of firms:

Hypothesis 3: Human capital in the form of CEOs' education will be positively associated with revenue growth in both immigrant-run businesses and businesses run by natives.

The interplay between social, human, and financial capital is important (Ram,

Theodorakopoulos and Jones, 2008; Vershinina, Barrett and Meyer, 2011) since these 
different forms of capital may substitute and also complement each other, such as when an individual relies on his or her network to take a short-term loan for his or her business rather than going to the bank (Bates, 1994).

Social capital is commonly defined as network connectedness, trustworthiness, and norms that result in economic and/or political benefit (Coleman, 1988; Lee, 2009). In entrepreneurship, a core mechanism of social capital is that resources embodied in social networks facilitate business (Davidsson and Honig, 2003). The network ties that enhance social capital are often divided into "bonding" and "bridging" ties (Putnam, 2000; Schuller, 2007). While some argue that social capital in terms of ethnic networks may alleviate a lack of financial and human capital resources (Hart and Acs, 2011; Portes and Sensenbrenner, 1993 ), others argue that the social capital benefiting the successful establishment of immigrant businesses in low-value sectors may not be useful for growth (Ram and Jones, 2008). Second-generation immigrant entrepreneurs may also be constrained by having the same type of bonding capital as their first-generation co-ethnics and may try to break out and acquire bridging social capital, which facilitates resource acquisition and potential firm growth (Deakins, Ishaq, Smallbone, Whittam and Wyper, 2007). These differential predictions highlight the need to distinguish between bonding and bridging social capital when studying small firm growth.

Bonding social capital refers to connections within social and ethnic groups that offer security and resource provisions within the group (Portes, 1998; Portes and Sensenbrenner, 1993 ). Immigrant entrepreneurs, especially those in the first generation, have been shown to often rely on bonding social capital in their businesses given the availability of tight networks in geographic proximity (Kelly, 1995; Sanders and Nee, 1996). The assumed mechanism in this regard is that individuals belonging to large migrant groups do not necessarily exhibit more or less bonding social capital; however, accessing sources of bonding social capital is 
intimately related to the size of such individuals' ethnic community (e.g. Collier, 2013; Ram et al., 2008; Vershinina et al., 2011). Regional proximity to co-ethnics may provide minority entrepreneurs with informal resources, such as business advice, introductions to customers and suppliers, and temporary labor (Kwon and Ruef, 2015). We therefore hypothesize:

Hypothesis 4a: Bonding social capital based on proximal kinship ties will be more important for revenue growth in immigrant-run businesses that for revenue growth in businesses run by natives.

Bridging social capital refers to resources embedded within "weak ties," a broader set of more diverse contacts that are more likely to contain resource-rich actors (Portes, 1998). A common source of such weak ties in business settings comes from firms' boards, which are often highly correlated with CEOs' personal networks in small firms (Mizruchi and Stearns, 1988). Bridging social capital in the form of intra-board networks is particularly important for minority entrepreneurs, who are often marginalized from established corporate networks (Light and Dana, 2013). Compared to first-generation immigrants, who tend to rely on kinship-based networks, second-generation immigrants may have better access to bridging social capital through more varied networks contacts (Deakins et al., 2007). This suggests that bridging social capital may be differentially related to the growth of firms run by immigrants in the first or second generation. This leads to our next hypothesis:

Hypothesis 4b: Bridging social capital based on ties to board directors will be more important for revenue growth in second-generation immigrant-run businesses that for firstgeneration immigrant-run businesses.

\section{Sector segregation among first- and second-generation immigrant firms}

An important difference between native and immigrant entrepreneurs is their firms' industry sectors. Previous studies have indicated that immigrants are often more confined to sectors with low entry barriers than natives (Ram and Jones, 2008). However, research has reached 
different conclusions in terms of whether second-generation immigrants manage to break out and run businesses targeting mainstream customers. Rusinovic (2008) and Baycan-Levent, Nijkamp and Sahin (2009) showed that second-generation immigrants more often run firms serving mainstream markets than their first-generation counterparts. However, Beckers and Blumberg's (2013) study did not find major differences regarding the industry sectors of firstand second-generation immigrant entrepreneurs except for second-generation Chinese entrepreneurs, who frequently ran firms in sectors that were different from those of the firstgeneration firms (Beckers and Blumberg, 2013). A likely mechanism that positions secondgeneration immigrant entrepreneurs for growth is thus whether they are able to enter a broader set of industry sectors than their parents (Ndofor and Priem, 2011). Thus, breaking out and targeting a mainstream market may allow them to surmount the growth barriers and limitations set by a confined ethnic market and/or industries with limited growth potential (Jones, Barrett and McEvoy, 2000; Rusinovic, 2008; Ward, 1986).

Further, due to intergenerational shifts, children of first-generation immigrants tend to increase their cultural capital by learning the language and culture of the host country (Zhou, 1997a) and, consequently, the options available for how to engage in business (Farley and Alba, 2002). If second-generation immigrants are able to break out from the traditional sectors that usually confine first-generation immigrants and pursue opportunities in more high-valueadded sectors, this may facilitate growth (Deakins et al., 2007). Thus, our final hypothesis is that entrepreneurs' choice of industry will be different among second-generation immigrants compared to first-generation immigrants (Ram and Carter, 2003):

Hypothesis 5: The industry sectors of second-generation immigrant businesses resemble the industry sectors of businesses run by natives more than the industry sectors of first-generation immigrant businesses.

\section{Methods and data}


Our study uses detailed register-based employment statistics from Statistics Sweden (SCB) (the official census bureau) on all legal residents of Sweden. It includes financial and demographic information and is generated from individual tax statements, financial records, school records, and birthplace registries. The data also includes information on firms, including employment, industrial structures, and the identity of company board members. The database we use was created in 2004 , the starting point of our study.

The original sample comprises the whole Swedish economy and comes with novel potential. First, it enables us to link demographic data on firms' individual CEOs, performance, and board members. Such data is normally difficult to find for private firms (George, 2005). Second, this sample allows us to track firms over time, investigating the influence of CEOs' background, firm-level factors, and board factors on outcomes like firm growth.

We sampled only incorporated firms with at least one employee in addition to the founder to avoid part-time businesses (Folta, Delmar and Wennberg, 2010). Firms with more than 100 employees were excluded since the ownership of such firms is often diluted, and they are usually run by management teams rather than a sole CEO, which is less appropriate when analyzing the effects of CEO background on firm-level outcomes (Davidsson and Wiklund, 2001).

We used SCB's Entrepreneurship Database for information on CEOs, which we define as "the person responsible for the day to day management of the firm" (Andersson and Andersson, 2012). This definition is theoretically founded as entrepreneurs who are ownermanagers of firms with at least one employee in addition to the founder (Brockhaus, 1980).

A novel aspect of our data is that we distinguish between CEOs based on their background: native CEO, first-generation immigrant CEO (from an OECD country or a nonOECD country), and second-generation immigrant CEO (from an OECD country or a non- 
OECD country). Due to confidentially, SCB does not report data on immigrants' country of origin but rather the region. ${ }^{1}$ Given (1) the focus on "dissimilar" CEOs in terms of variance in the economic and social situations between the individual's country of birth and Sweden, (2) the necessity to group immigrants to adhere with SCB's confidentiality procedure, and (3) the constraints on data analyses necessitating many degrees of freedom to accommodate necessary control variables, we chose to study two large groups of immigrants: those from OECD countries and those from non-OECD countries as well as their children. This broad distinction is generally salient in Western Europe given the region's data restrictions and follows several prior studies (Baycan-Levent and Nijkamp, 2009; Longva and Raaum, 2003). In our study "native CEO" refers to CEOs born in Sweden with at least one parent born in the country. With "first-generation immigrant CEO from an OECD country," we mean a person born in any OECD country except Sweden who is now running a firm. Out of all firstgeneration immigrants in Sweden, approximately $12 \%$ are from Finland. This necessitated some reflections and analysis as to what extent the group of Nordic immigrants should be merged with immigrants from other OECD countries. ${ }^{2}$ Second-generation immigrants are defined as individuals born in Sweden whose parents were born abroad (again separated into OECD and non-OECD countries). ${ }^{3}$ The sampling procedure yielded 50,002 unique firms and 187,008 firm-year observations over four years (2004-2008), excluding one year when lagging all predictors. These firms are summarized in Table 1.

$* * * * * * * * * * * * * * * * * * * * * * * * * * * * * *$

\footnotetext{
${ }^{1}$ The regions are Nordic countries, EU15 countries (excluding Nordic countries), Europe (excluding EU15/Nordic countries), former Soviet Union countries, Africa, North America (including Central America), South America, Asia (including Turkey and Cyprus), and Oceania.

${ }^{2}$ Language similarities among Nordic countries make merging Nordic immigrants with non-Nordic immigrants from other OECD countries a potentially inappropriate comparison base. In unreported robustness models, we estimated the same set of models merging OECD immigrants from Nordic countries with the Swedish group instead of the OECD immigrant group. The results were identical in direction and significance levels.

3 Swedish-born CEOs having one parent from an OECD country (other than Sweden) and the other parent from a non-OECD country were classified as second-generation immigrant entrepreneurs from an OECD country. We found only eight such cases.
} 


\section{Dependent variable: Revenue growth}

Previous studies have primarily measured growth using number of employees or firm revenue (Wright and Stigliani, 2013). We opted to use revenue growth as the dependent variable as many scholars consider this factor to be the most general measure of growth independent of industry (Delmar, 1997). Using employment growth as a token of business performance fails to consider that small businesses are increasingly contracting services and that there might be differences in the propensity to outsource between immigrants and natives (Hätönen and Eriksson, 2009). We followed past research in firm growth that measures growth as a ratio of size in the next time period and the current time period, making the growth rate equal to this ratio minus 1 (Coad, 2008; Delmar and Wennberg, 2010; Sorenson, 2003). The specification is based on Gibrat's law of size-independent growth (Daunfeldt and Elert, 2013), defined as follows:

$$
\frac{S_{i, t+1}}{S_{i t}}=S_{i t}^{(\propto-1)} \exp \left(X_{i t} \beta_{x}+y+\varepsilon\right)
$$

In equation (1), $S$ is the size of revenue for firm ${ }_{i}$ at time ${ }_{t}$, and the left-hand side of the equation $S_{t+1} / S_{t}$ is thus the growth in size from one year to another. The right-hand side of the equation contains the growth rate $\operatorname{sign} \propto-1$, which is equal to 0 if growth is sizeindependent. The right-hand side also includes the predictor variables $\mathrm{X}$ we are interested in investigating. Since these enter the model in exponential form, we need to log equation (1) to provide a function suitable for linear estimation: 


$$
\left.\ln \left(S_{i, t+1}\right)=\propto \ln \left(S_{i t}\right)++X_{i t} \beta_{x}+y+\varepsilon\right)
$$

In equation (2) the left-hand side of the equation represents the natural log of revenues size $\mathrm{S}$ for firm $i$ at time ${ }_{t+1}$. The right-hand side of the equation includes the natural log of revenues size $S$ for firm ${ }_{i}$ at time $t_{t+1}$; a number of predictor variables $X$ in firm ${ }_{i}$ at time $t$ together with their $\beta$ coefficients; and a control variable $\mathrm{y}$, which denotes the firm's relative size compared to the industry. $\varepsilon$ is the error term. Standard errors were clustered on the firm level to avoid autocorrelation. All predictor variables were lagged one year to avoid simultaneity bias (i.e., variables measured in 2004 were regressed on growth between 2004 and 2005, etc.).

\section{Independent variables}

Native CEO: Our main comparison variable is an indicator for native CEOs. This variable takes the value 1 for CEOs born in Sweden with at least one parent also born in Sweden and 0 otherwise (Behrenz, Hammarstedt and Månsson, 2007).

First-generation immigrant CEO from an OECD country. Previous research has highlighted the relevance of distinguishing between immigrants from economically and culturally dissimilar regions (e.g. Baycan-Levent and Nijkamp 2009; Longva and Raaum 2003).

Following this research approach, we created a variable taking the value 1 for CEOs born outside Sweden in any OECD country ${ }^{4}$ and 0 otherwise.

First-generation immigrant CEO from a non-OECD county. Similar to the above variable, a second variable was created taking the value 1 for CEOs born outside Sweden in any nonOECD country and 0 otherwise.

\footnotetext{
${ }^{4}$ Australia, Austria, Belgium, Canada Chile, Czech Republic, Denmark, Estonia, Finland, France, Germany, Greece, Hungary, Iceland, Ireland, Israel, Italy, Japan, Korea, Luxembourg, Mexico, the Netherlands, New Zealand, Norway, Poland, Portugal, Slovak Republic, Slovenia, Spain, Sweden, Switzerland, Turkey, the United Kingdom, and the United States.
} 
Second-generation immigrant CEO from an OECD country. This variable takes the value 1 for CEOs born in Sweden but with both parents born in OECD countries other than Sweden (Behrenz et al., 2007).

Second-generation immigrant CEO from a non-OECD country. Similar to the above variable, a second variable was created that takes the value 1 for CEOs born in Sweden but whose parents were born in non-OECD countries and 0 otherwise.

(Ln) CEO net wealth. Prior studies have indicated that owner-managers' financial resources might be beneficial for small firm growth, particularly among immigrants (Basu and Goswami, 1999). We included a variable measuring CEOs' net wealth, which was highly non-linear and was therefore entered in logarithmic form.

CEO post-secondary education. Managers' education may impact firm growth (Wiklund, Davidsson and Delmar, 2003). We included a dummy variable taking the value 1 for CEOs with a three-year or longer post-secondary education and 0 otherwise.

Board interlocks. We used members who sit on several boards as an indication of "bridging" social capital between firms, signifying the presence of resourceful members on a firm's board. Such social capital resources may affect firm growth by providing firms access to knowledge and opportunities as board members exchange ideas and thoughts (Mizruchi and Stearns, 1988). We studied board interlocks by measuring if a person is a member of two firms' board of directors. If the individual is a member of both Boards A and B, there is a connection between the firms.

County share of OECD immigrants/county share of non-OECD immigrants. Immigrants' benefit from proximity of kin both when it comes to labor market opportunities (Edin, Fredriksson and Åslund, 2003) and entrepreneurship (Bird and Wennberg, 2014). Proximity to kin brings about close social ties, a form of bonding social capital (Putnam, 2000; Schuller, 2007) that can contribute to entrepreneurial success (Portes and Sensenbrenner, 1993 ). 
Similar to Edin and colleagues (2003), we approximated this effect by measuring the proportion of residents in the county where a CEO resides who are immigrants from the same region as the CEO.

Industry. To investigate differences in industry sector among immigrant entrepreneurship in the first or second generation, we introduced dummy variables for industry sector using SIC1-equivalent codes (Daunfeldt and Elert, 2013). The industry sectors are outlined in Table 6.

\section{Control variables}

CEO minority shareholder. This variable indicates whether the CEO is not a majority shareholder, which suggests that he or she is not a sole decision maker in the firm. This variable takes the value 1 for CEOs who are not major shareholders in the firm and 0 otherwise. Robustness tests separated by this variable impacted the main results marginally, so we kept this variable as a control.

CEO's partner runs a firm. This variable controls for family patterns in entrepreneurship by a dummy variable taking the value 1 if the CEO's partner is self-employed and 0 otherwise. CEO's parents run a firm. Cultural capital provided by entrepreneurial parents may shape children through exposure to entrepreneurship (Sørensen, 2007). We controlled for this with a variable taking the value 1 if one of the CEO's parents is self-employed and 0 otherwise. Female CEO. Firms run by female CEOs often exhibit lower growth rates although not lower profitability (Du Rietz and Henrekson, 2000). We included a variable taking the value 1 for female CEOs and 0 otherwise.

Number of board members. To ensure our measure of board interlocks is not tainted by the relative size of boards, we included a variable measuring the number of board members on each firm's board. 
CEO family size. Family members are defined as a CEO's partner, parents, partner's parents, siblings, and partner's siblings, and children (15 years or older).

Corporate group. This is a dummy variable taking the value 1 for firms that are wholly or partly owned by another firm as the CEO's influence over growth might be different.

Relative firm size. The relative size of firms compared to what is common in their industry is known to strongly affect subsequent growth (Daunfeldt and Elert 2013). We measured this variable as a firm's relative size in revenue compared to the industry average on the most fine-grained industry classification available (i.e., SIC-5-equivalent level). ${ }^{5}$

Employees' tertiary education (\%). The share of employees who have a three-year or longer post-secondary education.

Firm age. Number of years since the firm became active in SCB's registry.

County. Since regions offer distinct opportunities for growth, we controlled for firms' regional headquarters using 21 dummy variables for each of the main Swedish county regions.

$* * * * * * * * * * * * * * * * * * * * * * * * * * * * * *$

TABLES 2 AND 3 HERE

$* * * * * * * * * * * * * * * * * * * * * * * * * * * * * *$

Table 2 displays the proportion of CEOs in Swedish firms during the 2005-2008 time period split according to immigrant background. Variables descriptives are presented in Table 3. The revenue variable is not normally distributed, which may cause problems in the growth regression. Therefore, we performed a number of robustness tests. First, we used the logarithm of revenue growth, which did not cause major changes in our results. Second, we

\footnotetext{
${ }^{5}$ Unreported models replaced this variable with number of employees, which did not affect the main results.
} 
estimated models based on revenue instead of revenue growth. The results remained similar but with considerably higher explanatory power. Correlations between the different variables (omitted due to space constraints) exhibited low to moderate correlation with little danger of multicollinearity.

\section{Results}

We started our analysis of firm growth with descriptive analyses of growth measured as relative change in revenue. Growth is highly uneven, with some shrinking firms, a majority of relatively slowly growing firms (see Table 1), and some rapidly growing firms. Therefore, we supplemented our main analyses with a quantile regression to tease out the contextual boundaries of our main effects (Welter, 2011).

Figures 1 and 2 show the average revenue among firms run by native CEOs, firstgeneration immigrant CEOs (from OECD/non-OECD countries), and second-generation immigrant CEOs (from OECD/non-OECD countries). Firms with native CEOs are, on average, 10-20\% larger in terms of revenues than firms for which the CEO has an immigrant background. Among firms run by immigrant CEOs, there are no clear differences in terms of revenues in Figure 1 depending on whether the CEO or his or her parents immigrated from an OECD or a non-OECD country.

Figure 2 shows average growth rates for the same group of firms as in Figure 1. This reveals a different picture than looking at average revenue level: firms run by secondgeneration immigrants from OCED countries and firms run by first-generation immigrants from non-OCED countries exhibit, on average, higher growth. This highlights the important differences of firm size and firm growth and suggests that the region from which the CEO or his or her parents emigrated is important in explaining growth in immigrant-run small businesses. 


\section{Growth among firms led by immigrants and natives}

To test our two first hypotheses, we analyzed growth among firms led by first- and secondgeneration immigrant CEOs in comparison to native CEOs. We analyzed firm growth using panel regression with random CEO effects, as shown in Table 4. The table presents the random effects panel model for the whole sample of firms with dummy variables for first- and second-generation immigrant CEOs (from OECD and non-OECD countries).

$* * * * * * * * * * * * * * * * * * * * * * * * * * * * * *$

TABLE 4 HERE

$* * * * * * * * * * * * * * * * * * * * * * * * * * * * * *$

Table 4 shows our base model for firms' revenue growth. The explanatory power (R2) value is low, which occurs frequently in studies of small firms, for which growth is often irregular (Delmar, McKelvie and Wennberg, 2013; Wright and Stigliani, 2013). The dummy variable for firms run by second-generation OECD immigrants is positive and significant in the random effects panel model $(0.023, \mathrm{p}<0.01)$. However, the dummy variable for firms whose CEO is a second-generation non-OECD immigrant is negative (-0.019) albeit not statistically significant at $\mathrm{p}<0.05$. This provides partial support for Hypothesis 1 but full support for Hypothesis 2. Revenue growth is indeed higher in second-generation immigrant businesses 
compared to firms run by first-generation immigrants but only for those who come from OECD countries.

In terms of coefficient sizes, the effects of CEO background are comparatively strong. The effects are stronger than the coefficient for CEO's parents run a firm, which is generally considered to be an important predictor. These findings indicate that the CEO's origin significantly affects revenue growth and that firms run by second-generation immigrants develop differentially compared to firms run by first-generation immigrants. An explanation for the differences in growth trajectories between these groups could be the latter group's relative lack of bridging social capital. Having grown up in another country, the first generation's relative lack of host country social capital may make them less able to access social circles that can be of key benefit for establishing and growing a business. This also raises interesting questions regarding the determinants of growth within these groups of firms. Could it be that separate capital resources (i.e., financial, human, or social capital) affect the growth of small firms differentially given CEOs' background? We subsequently attend to this question by estimating regression models separated by the different groups of CEOs.

\section{Difference in growth factors among firms led by first- and second-generation immigrants}

Figure 1 and the regression analyses shown in Table 4 show that even if firms run by secondgeneration OECD immigrants are generally smaller, they tend to grow faster than companies with native CEOs. ${ }^{6}$ To explore Hypotheses 3 and 4 related to the effects of specific types of capital resources for the growth of immigrant businesses, we estimated separate random effects models for firms run by the five groups of CEOs, as shown in Table 5.

$* * * * * * * * * * * * * * * * * * * * * * * * * * * * * *$

\footnotetext{
${ }^{6}$ Our growth measure control for differences in industry size across firms; hence, it is a measure of relative growth.
} 
Table 5 reveals points concealed in the previous analyses. Overall, firms run by secondgeneration immigrants seem to be driven by partially distinct factors compared to firms led by native CEOs or first-generation CEOs. First, we find CEO post-secondary education, our proxy for human capital, associated with the revenue growth of firms run by natives but not for any of the other (immigrant) groups $(0.010, \mathrm{p}<0.05){ }^{7}$ This provides only partial support for Hypothesis 3, which predicted that CEO education would be positively associated with revenue growth in all businesses. Together with the very weak impact of the control variable CEO wealth, these results suggests that differences in human and financial capital cannot explain why second-generation OECD immigrants outperform both their non-OECD peers and all groups of first-generation immigrants. We thus move on to examine Hypotheses 4a and $4 \mathrm{~b}$, which attended to the role of bonding and bridging social capital for the growth of immigrant-run firms.

While it is impossible to explore all possible facets of bridging and bonding social capital in a study based on register-based data such as ours, we used two of the most wellresearched facets in the field: bonding social capital based on proximal kinship ties and bridging social capital based on ties to company directors (Edin et al., 2003; Mizruchi and Stearns 1988).

Looking first at the proxies for bonding social capital in terms of the variables county share of OECD immigrants and county share of non-OECD immigrants in Table 5, we note weak differential patterns depending on the group of CEOs investigated. County share of nonOECD immigrants is positively associated with revenue growth among second-generation

\footnotetext{
${ }^{7}$ When interpreting the effects in Table 5 one needs to remember that the sample sizes of the different groups of CEOs are different, with the native CEO group being vastly larger than the others. This also explains why some weaker coefficients are significant only in the native CEO group.
} 
OECD CEOs (7.290. $\mathrm{p}<0.05)$; whereas county share of OECD immigrants is negatively associated with revenue growth among native CEOs $(-1.980, \mathrm{p}<0.01)$. These results do not support Hypothesis 4a, which suggested that bonding social capital based on proximal kinship ties is important for revenue growth in all immigrant-run businesses. A potential explanation is that running businesses in an ethnic enclave may enhance growth if the enclave is populated by groups with moderate incomes, but is of less benefit if the enclave is populated by lowincome groups (Edin et al., 2003). The weaker purchasing power in areas containing a high proportion of immigrants is a plausible explanation for this negative influence on revenue growth among native-run businesses.

Looking next at the variable board interlocks in Table 5, our proxy for bridging social capital, we find this variable to be positively associated with revenue growth for firms run by second-generation non-OECD immigrants $(0.026, \mathrm{p}<0.05)$ but not for the other categories, for which the control variable number of board members is more reflective of revenue growth. This provides partial support for Hypothesis $4 \mathrm{~b}$, which argued that bridging social capital based on ties to company directors' would affect revenue growth in second-generation immigrant-run businesses, more than their first-generation counterparts. We find, however, that bridging social capital is conducive for growth only among the more marginalized group of second-generation immigrant CEOs from non-OECD countries. Overall, these patterns indicate that bridging social capital based on ties to company directors and bonding social capital based on proximal kinship ties are associated with small firm growth but only weakly so, and the effects differ across groups of firms.

It is also noteworthy that CEO's parents running a firm is positively associated with revenue growth for both native CEOs $(0.017, \mathrm{p}<0.01)$ and second-generation OECD immigrant CEOs $(0.051, \mathrm{p}<0.01)$ but not among the other groups. A possible explanation for why parental entrepreneurship is associated with firm growth only among native and second- 
generation immigrant CEOs may be that upon leaving their home country, first-generation immigrant entrepreneurs experience a break in their life that may reduce the occupational inheritance of entrepreneurship. ${ }^{8}$

\section{Industry sector among firms run by first- and second-generation immigrant CEOS}

Hypothesis 5 hypothesized that the industry sectors of second-generation immigrant businesses are more similar to those of businesses run by natives compared to those of firstgeneration immigrant businesses. Table 6 shows the distribution of industry sectors for the firms. The table shows systematic differences depending on CEO background in regard to the sectors in which the firms are active. Native CEOs dominate within the traditional sectors of agriculture, forestry, and fishery. Firms led by first-generation immigrant CEOs are more often active in the personal and cultural services sectors, including both OECD immigrants (18.4\%) and non-OECD immigrants (36.7\%). The corresponding figures for secondgeneration immigrant CEOs are markedly lower (12.1\% and 4.1\%, respectively). A likely explanation is that the restaurant industry within the personal and cultural services sector is an industry in which first-generation immigrants have traditionally been over-represented due to low entry barriers (Bates 2011; Ram and Jones 2008).

Comparing the last two rows of Table 6 showing the industry distribution of secondgeneration immigrant CEOs with the first row (for natives) and the second to third row (for first-generation immigrant CEOs) we see a marked shift in that the industry sectors of secondgeneration immigrant businesses more strongly resemble the industry sectors of businesses run by natives, compared to the sectors of first-generation immigrant businesses (Kloosterman, 2010).

\footnotetext{
${ }^{8} \mathrm{We}$ are grateful to an anonymous referee for pointing this out.
} 
This supports Hypothesis 5 in that the industry sectors of second-generation immigrant businesses more strongly resemble the industry sectors of businesses run by natives, compared to the sectors of first-generation immigrant businesses. ${ }^{9}$ Second-generation immigrants' tendency to choose to run businesses in sectors with higher entry barriers constitute one reason why their firms could potentially grow more rapidly. Differences in sector composition are important for firm growth since growth opportunities differ across sectors (Daunfeldt and Elert, 2013) and immigrant entrepreneurs operating in knowledgeintensive sectors are better positioned for growth compared to those in other sectors (Ram and Carter, 2003).

\section{Growth among slow-growing and fast-growing firms}

Our final analysis investigated whether the factors that affect growth are different between slow-growing and fast-growing firms. We performed this analysis by splitting up the firms in growth quantiles and estimating models using quantile regression (Goedhuys and Sleuwaegen, 2010). The results in Table 7 show interesting patterns beyond the results shown in Table 4. Specifically, post-secondary education is positively associated with revenue growth for the $70^{\text {th }}$ quantile $(0.005, \mathrm{p}<0.01)$ and the $90^{\text {th }}$ quantile $(0.023, \mathrm{p}<0.01)$, suggesting that while education is not important for growth in general, it is important for high growth (Basu and Goswami, 1999).

The indicator variables for CEO background in Table 7 affirm the patterns shown in Table 4: the indicator variable for first-generation immigrant CEOs from outside OECD countries is negatively associated with growth only in the $10^{\text {th }}$ quantile $(-0.016, p<0.05)$, but the indicator variable for first-generation immigrant CEOs from OECD countries is negatively associated with growth in all but the top quantile as is the indicator variable for second-

\footnotetext{
${ }^{9}$ The bivariate patterns outlined in Table 6 are supported by industry-level coefficients computed from Table 5 (available upon request).
} 
generation immigrant CEOs from outside OECD countries. Conversely, the indicator variable for second-generation immigrant CEOs from OECD countries is positively associated with revenue growth in all but the bottom quantile in the growth-rate distribution (coefficients ranging from 0.010 at $<0.05$ to $0.036, \mathrm{p}<0.01)$.

The variables approximating for bridging and bonding social capital in Table 7 indicate a positive association between board interlocks and growth for the $70^{\text {th }}(0.003, p<0.01)$ and $90^{\text {th }}(0.012, \mathrm{p}<0.01)$ quantiles in the growth-rate distribution, whereas the relationship is negative for the $10^{\text {th }}(-0.014, \mathrm{p}<0.01)$ and $30^{\text {th }}(-0.003, \mathrm{p}<0.01)$ quantiles. Further, the number of board members positively impacts growth for all quantiles except the $90^{\text {th }}$ quantile. The two variables for county share of (non-) OECD immigrants are erratically associated with growth at various quantiles in the growth-rate distribution, which precludes us from drawing any strong conclusions for this variable when it comes to rapid versus slow growth. This suggests the need for a moderating statement to Hypothesis $4 \mathrm{~b}$ : the quantile regression reveals that while board interlocks do not indicate any general relationship with the growth of immigrant-run or native-run firms, it does show a positive and fairly strong relationship with high growth.

$* * * * * * * * * * * * * * * * * * * * * * * * * * * * * *$

TABLE 7 HERE

$* * * * * * * * * * * * * * * * * * * * * * * * * * * * * *$

\section{Discussion}

We set out to investigate differences in revenue growth in a comparative study of native CEOs, first-generation OECD immigrant CEOs, first-generation non-OECD immigrant CEOs, second-generation OECD immigrant CEOs, and second-generation non-OECD immigrant CEOs. We sought to test the roles of human capital as well as bonding and 
bridging social capital for growth in immigrants' businesses and to examine whether differences in first- and second-generation immigrant firms could be explained by the segmented assimilation theory. Our study addresses the paucity of empirical research on the growth of immigrant-run firms, especially among firms run by second-generation immigrants (Aldrich and Waldinger, 1990; Bates, 2011).

We found that firms run by second-generation immigrant CEOs from OECD countries show higher growth rates than firms run by native CEOs as well as by first-generation immigrant CEOs although the average revenue is lower in all groups of immigrant-run firms. This indicates a pattern of upward socio-economic mobility among migrants of various generations in that the growth rates among firms run by second-generation immigrant CEOs from OECD countries are higher than the equivalent first-generation immigrant CEOs. The reverse, however, is true for firms run by second-generation immigrant CEOs from nonOECD countries, whose businesses grow markedly slower. Taken together, this contributes to theory by showing support for the segmented assimilation thesis rather than the universal assimilation thesis when it comes to the growth of immigrant businesses (Zhou, 1997b).

Human capital theory suggests that a fundamental resource for entrepreneurs is their general set of skills and knowledge, often approximated as general human capital. Our study showed that general human capital in the form of post-secondary education does not have any general association with the growth of small firms run by first- or second-generation immigrant CEOs. However, the quantile regressions showed that the effects of CEOs' postsecondary education are only strongly apparent for the fastest-growing firms (i.e., those in the $90^{\text {th }}$ quantile). Consequently, it appears that CEOs' human capital is of marginal importance for the vast number of firms regardless of CEO background, whereas for the small proportion of fast-growing firm, CEOs' human capital is one of the strongest predictors of firm growth. 
Our measure of bridging social capital - network contacts through board interlocks was positively associated with growth of firms run by second-generation entrepreneurs from non-OECD countries only. While this group of immigrant entrepreneurs exhibited lower growth than the other groups, to some extent bridging social capital resources could help them moderate the disadvantage of belonging to a less assimilated group (Portes and Zhou, 1993; Ram and Carter, 2003). Our proxy for bonding social capital - proximal kinship ties measured as number of immigrants in the county (Edin et al., 2003) - was weakly and erratically related to growth in our analyses. Further research using more detailed measures of bonding and bridging social capital derived from network analyses may develop these patterns in more depth.

The distinct differences between firms run by first- and second-generation immigrants in terms of entering certain sectors indicate that second-generation immigrants choose to run businesses in sectors with higher entry barriers than first-generation immigrants, potentially allowing them to grow more rapidly. This further supports the notion of segmented assimilation, which argues that second-generation immigrant entrepreneurs, primarily those from the more similar OECD countries, are more able to break into mainstream markets than the first generation.

The findings from our panel regressions on revenue growth among the specific group of entrepreneurs (Table 5) indicate that differences in growth patterns cannot be explained by discrepancies in CEOs' human and financial capital. We speculate that discrimination may partly explain the lower growth among second-generation immigrants from non-OECD countries since second-generation immigrants from these regions have been shown to exhibit weaker labor market attachment than those originating in Western/OECD countries (Rooth and Ekberg, 2003; Støren and Wiers-Jenssen, 2010). Having a CEO whom is being discriminated against may raise difficulties in raising financing from venture capitalists or 
banks, which in turn will have negative repercussions on growth (Blanchflower, Levine and Zimmerman, 2003; Cavalluzzo and Wolken, 2005; Cavalluzzo and Cavalluzzo, 1998).

Specific to the context we study, non-European immigrant entrepreneurs in Sweden have been shown to perceive higher levels of discrimination from banks, suppliers, and customers than natives. In addition, they often face a higher risk of having applications for bank loans turned down and generally pay higher interest rates on bank loans (Aldén and Hammarstedt, 2014). Whether discrimination actually occurs in the small business sector and how it affects growth and other measures of performance remains an important area for future studies on immigrant entrepreneurship.

Overall, we showed that entrepreneurship in the form of growing small firms may be relevant for the socio-economic inclusion of certain migrant groups but not all (Blackburn and Ram, 2006; Hjerm, 2004). Opportunities for socio-economic advancement in terms of small business growth in Sweden is noticeable among firms run by second-generation immigrant CEOs from OECD countries but not among firms run by second-generation immigrant CEOs from non-OECD countries, whose firms grows slower than the population average.

Our study also comes with limitations, several of which offer opportunities for future work. While we were able to include a wide array of firm-specific and CEO-specific factors in our models, an important factor not included is the CEO's personal network (Portes et al., 2002). Our network data is limited to that of firms' boards, which are often highly correlated to CEOs' personal networks in small firms. However, there are important theoretical distinctions between personal networks and intra-board networks (Mizruchi and Stearns, 1988).

Second, an important limitation concerns the heterogeneity of migrants depending on their country of origin. Our focus on a broad-population study rather than a narrow study of 
one immigrant group or a few specific immigrant groups entails a tradeoff between generality and specificity. A more fine-grained distinction of immigrants may yield distinct results.

Third, while our research design of sampling only smaller and mid-sized firms with fewer than 100 employees serves to minimize unobserved heterogeneity and thus increase internal validity, this comes with limitations regarding generalizability. It is obviously possible that CEOs' ethnicity also has effects on the growth rates of larger firms.

Fourth, our measures of social capital are based on indirect proxies in terms of geographical agglomeration of minorities and network measures on the firm level. More detailed network measures on the individual level would enhance these analyses of social capital among immigrant entrepreneurs (Light and Dana, 2013).

Finally, our findings that firms run by second-generation immigrant CEOs from OECD countries grow more rapidly than firms run by first-generation immigrants was interpreted as a case of breaking out from the precarious situation facing first-generation immigrant entrepreneurs, driven in part by second-generation immigrants' choosing to run firms in different industrial sectors than their parents. Other variables may further help explain this pattern, which represents a potentially fruitful line of further research in this age of increasing internationalization and migration (Carter et al., 2015).

\section{Conclusion}

This paper presented evidence on the patterns and predictors of growth among small firms managed by first- and second-generation immigrant CEOs in Sweden using a unique dataset. We found that firms run by second-generation immigrants from OECD countries exhibit higher growth than firms run by native CEOs, whereas firms run by second-generation immigrant CEOs from non-OECD countries exhibit lower growth. This suggests that economic integration in terms of small business growth in Sweden is characterized by 
segmented rather than universal assimilation. We hope other researchers will join us to further explore the important and expanding area of immigrant entrepreneurship, including the growth and development of immigrant-run firms.

\section{References}

Aldén L and Hammarstedt M (2014) Diskriminering på kreditmarknaden? En enkätundersökning bland utrikes födda egenföretagare. Ekonomisk Debatt 42(6): 5059.

Aldrich H E and Waldinger R (1990) Ethnicity and Entrepreneurship. Annual Review of Sociology, 16: 111-135.

Andersson F W and Andersson J (2012) En algoritm för att peka ut företagens operativa företagsledare i näringslivet $S C B$, Fokus på näringsliv och arbetsmarknad.

Andersson L and Hammarstedt M (2010) Intergenerational transmissions in immigrant selfemployment: Evidence from three generations. Small Business Economics 34(3): 261276.

Basu A and Goswami A (1999) South Asian entrepreneurship in Great Britain: factors influencing growth. International Journal of Entrepreneurial Behavior \& Research 5(5): 251-275.

Bates T (1990) Entrepreneur human capital and small business longevity. The Review of Economics and Statistics 72(4): 551-559.

Bates T (1994) Social Resources Generated by Group Support Networks May Not Be Beneficial to Asian Immigrant-Owned Small Businesses of Asian business success. Asian Business 72(March): 671-689.

Bates T (2011) Minority Entrepreneurship. Foundations and Trends in Entrepreneurship 7(34): 151-311.

Baycan-Levent T and Nijkamp P (2009) Characteristics of migrant entrepreneurship in Europe. Entrepreneurship \& Regional Development 21(4): 375-397.

Baycan-Levent T, Nijkamp P and Sahin M (2009) New orientations in ethnic entrepreneurship: motivation, goals and strategies of new generation ethnic entrepreneurs. International journal of foresight and innovation policy 5(1): 83-112.

Beckers P and Blumberg B F (2013) Immigrant entrepreneurship on the move: a longitudinal analysis of first-and second-generation immigrant entrepreneurship in the Netherlands. Entrepreneurship \& Regional Development 25(7-8): 654-691.

Behrenz L, Hammarstedt M and Månsson J (2007) Second-Generation Immigrants in the Swedish Labour Market. International Review of Applied Economics 21(1): 157-174.

Bird M and Wennberg K (2014) Regional influences on the prevalence of family versus nonfamily start-ups. Journal of Business Venturing 29(3): 421-436.

Bisin A, Patacchini E, Verdier T and Zenou Y (2011) Ethnic identity and labour market outcomes of immigrants in Europe. Economic Policy 26(65): 57-92.

Blackburn R and Ram M (2006) Fix or fixation? The contributions and limitations of entrepreneurship and small firms to combating social exclusion. Entrepreneurship and Regional Development 18(1): 73-89.

Blanchflower D G, Levine P B and Zimmerman D J (2003) Discrimination in the smallbusiness credit market. Review of Economics and Statistics 85(4): 930-943. 
Bourdieu P (1986) The forms of capital in Handbook of theory and research for the sociology of education, 241-258: New York: Greenwood.

Brockhaus R H, Sr. (1980) Risk taking propensity of entrepreneurs. Academy of Management Journal 23(3): 509-520.

Carlsson M and Rooth D-O (2007) Evidence of ethnic discrimination in the Swedish labor market using experimental data. Labour Economics 14(4): 716-729.

Carter S, Mwaura S, Ram M, Trehan K and Jones T (2015) Barriers to ethnic minority and women's enterprise: Existing evidence, policy tensions and unsettled questions. International Small Business Journal 33(1): 49-69.

Cavalluzzo K and Wolken J (2005) Small Business Loan Turndowns, Personal Wealth, and Discrimination. The Journal of Business 78(6): 2153-2178.

Cavalluzzo K S and Cavalluzzo L C (1998) Market structure and discrimination: The case of small businesses. Journal of Money, Credit and Banking 30(4): 771-792.

Chaganti R and Greene P (2002) Who Are Ethnic Entrepreneurs? A Study of Entrepreneurs' Ethnic Involvement and Business Characteristics*. Journal of Small Business Management 40(May 1999): 126-143.

Coad A. (2008). Firm Growth : A Survey (CES Working Paper No. 2007.24). Paris: Centre d'Economie de la Sorbonne.

Coleman J (1988) Social capital in the creation of human capital. American Journal of Sociology 94: 95-120.

Collier P (2013) Exodus: How migration is changing our world: Oxford University Press.

Colombo M G and Grilli L (2005) Founders' human capital and the growth of new technology-based firms: A competence-based view. Research Policy 34(6): 795-816.

Daunfeldt S-O and Elert N (2013) When is Gibrat's law a law? Small Business Economics 41(1): 133-147.

Davidsson P and Honig B (2003) The role of social and human capital among nascent entrepreneurs. Journal of Business Venturing 18(3): 301-331.

Davidsson P and Wiklund J (2001) Levels of analysis in entrepreneurship research: current practice and suggestions for the future. Entrepreneurship Theory \& Practice 25(4): 81-99.

Deakins D, Ishaq M, Smallbone D, Whittam G and Wyper J (2007) Ethnic minority businesses in Scotland and the role of social capital. International Small Business Journal 25(3): 307-326.

Delmar F (1997) Measuring growth: methodological considerations and empirical results. In R. Donckels \& A. Miettinen (Eds.), (pp. 199-216). Aldershot, England: Ashgate.

Delmar F, Davidsson P and Gartner W B (2003) Arriving at the high-growth firm. Journal of Business Venturing 18(2): 189-216.

Delmar F, McKelvie A and Wennberg K (2013) Untangling the relationships among growth, profitability and survival in new firms. Technovation 33(8-9): 276-291.

Delmar F and Wennberg K (2010) The Birth, Growth, and Demise of Entrepreneurial Firms in the Knowledge Intensive Economy. Cheltenham: Edward Elgar.

Du Rietz A and Henrekson M (2000) Testing the female underperformance hypothesis. Small Business Economics 14(1): 1-10.

Edin P-A, Fredriksson P and Åslund O (2003) Ethnic enclaves and the economic success of immigrants: Evidence from a natural experiment. The Quarterly Journal of Economics 118(1): 329-357.

Fairlie R W (2005) Entrepreneurship and earnings among young adults from disadvantaged families. Small Business Economics 25(3): 223-236.

Fairlie R W (2012) Open for Business: How Immigrants are Driving Small Business Creation in the United States. 
Farley R and Alba R (2002) The new second generation in the United States. International migration review 36(3): 669-701.

Folta T B, Delmar F and Wennberg K (2010) Hybrid Entrepreneurship. Management Science 56(2): 253-269.

Fredlund-Blomst S. (2014). Assessing Immigrant Integration in Sweden after the May 2013 Riots. In Migration Policy Institute. Available at:

http://www.migrationpolicy.org/article/assessing-immigrant-integration-sweden-aftermay-2013-riots (accessed at 10 April 2015).

George G (2005) Slack resources and the performance of privately held firms. Academy of Management Journal 48(4): 661-676.

Goedhuys M and Sleuwaegen L (2010) High-growth entrepreneurial firms in Africa: a quantile regression approach. Small Business Economics 34(1): 31-51.

Hart D M and Acs Z J (2011) Immigration and High-Impact, High-Tech Entrepreneurship. (6): $1-11$.

Hjerm M (2004) Immigrant entrepreneurship in the Swedish welfare state. Sociology 38(4): 739-756.

Hätönen J and Eriksson T (2009) 30+ years of research and practice of outsourcing-Exploring the past and anticipating the future. Journal of International Management 15(2): 142155.

Jones T, Barrett G and McEvoy D (2000) Market potential as a decisive influence on the performance of ethnic minority business. In: Rath J (ed.) Immigrant businesses: The economic, political and social environment. Basingstoke: Macmillan, pp. 37-53.

Jones T, Ram M and Theodorakopoulos N (2010) Transnationalism as a force for ethnic minority enterprise? The case of Somalis in Leicester. International Journal of Urban and Regional Research 34(3): 565-585.

Kelly M P F (1995) Social and cultural capital in the urban ghetto: Implications for the economic sociology of immigration. New York: Russell Sage Foundation.

Kloosterman R C (2010) Matching opportunities with resources: a framework for analysing (migrant) entrepreneurship from a mixed embeddedness perspective.

Entrepreneurship and Regional Development 22(1): 25-45.

Kwon S-W and Ruef M (2015) The Imprint of Local Labor Markets on Entrepreneurial Performance. Paper presented at the Academy of Management Conference, Vancouver.

Lee R (2009) Social capital and business and management: Setting a research agenda. International Journal of Management Reviews 11(3): 247-273.

Light I (1979) Disadvantaged minorities in self-employment. International Journal of Comparative Sociology 20(1-2): 31-45.

Light I and Dana L P (2013) Boundaries of social capital in entrepreneurship. Entrepreneurship Theory and Practice 37(3): 603-624.

Light I H and Rosenstein C N (1995) Race, ethnicity, and entrepreneurship in urban America: Transaction Publishers.

Longva P and Raaum O (2003) Earnings assimilation of immigrants in Norway-A reappraisal. Journal of Population Economics 16(1): 177-193.

Mizruchi M S and Stearns L B (1988) A longitudinal study of the formation of interlocking directorates. Administrative Science Quarterly 33(2): 194-210.

Ndofor H and Priem R L (2011) Immigrant Entrepreneurs, the Ethnic Enclave Strategy, and Venture Performance. Journal of Management 37(3): 790-818.

Panayiotopoulos P I (2006) Immigrant Enterprise in Europe and the USA: Routledge.

Portes A (1998) Social Capital: Its Origins and Applications in Modern Sociology. Annual Review of Sociology 24(1): 1-24. 
Portes A, Guarnizo L E and Haller W J (2002) Transnational entrepreneurs: An alternative form of immigrant economic adaptation. American Sociological Review 67(2): 278298.

Portes A and Rumbaut R G (2001) Legacies: The story of the immigrant second generation: Univ of California Press.

Portes A and Sensenbrenner J (1993) Embeddedness and immigration: Notes on the social determinants of economic action. American Journal of Sociology 98(6): 1320-1350.

Portes A and Zhou M (1993) The New Second Generation: Segmented Assilation and Its Variants among Post-1965 immigrant Youth. The Annals of the American Academy of Political Sciences 530(1): 74-96.

Putnam RD (2000) Bowling alone: The Collapse and Revival of American Community. New York: Simon and Schuster.

Ram M and Carter S (2003) Paving Professional Futures Ethnic Minority Accountants In the United Kingdom. International Small Business Journal 21(1): 55-71.

Ram M and Jones T (2008) Ethnic-minority businesses in the UK: a review of research and policy developments. Environment and planning. C, Government \& policy 26(2): 352.

Ram M, Jones T, Edwards P, Kiselinchev A, Muchenje L and Woldesenbet K (2013) Engaging with super-diversity: New migrant businesses and the research-policy nexus. International Small Business Journal 31(4): 337-356.

Ram M, Theodorakopoulos N and Jones T (2008) Forms of capital, mixed embeddedness and Somali enterprise. Work, Employment \& Society 22(3): 427-446.

Renzulli L A and Aldrich H (2005) Who can you turn to? Tie activation within core business discussion networks. Social Forces 84(1): 323-341.

Rooth D-O and Ekberg J (2003) Unemployment and earnings for second generation immigrants in Sweden. Ethnic background and parent composition. Journal of Population economics 16(4): 787-814.

Ruef M (2002) Strong ties, weak ties and islands: structural and cultural predictors of organizational innovation. Industrial and Corporate Change 11(3): 427-449.

Rusinovic K (2008) Moving between markets? Immigrant entrepreneurs in different markets. International Journal of Entrepreneurial Behaviour \& Research 14(6): 440-454.

Rydgren J (2004) Mechanisms of exclusion: ethnic discrimination in the Swedish labour market. Journal of Ethnic and Migration Studies 30(4): 697-716.

Sanders J M and Nee V (1996) Immigrant self-employment: The family as social capital and the value of human capital. American Sociological Review 61(2): 231-249.

Schierup C-U, Hansen P and Castles S (2006) Migration, citizenship, and the European welfare state: a European dilemma. Oxford University Press.

Schuller T (2007) Reflections on the use of social capital. Review of Social Economy 65(1): 11-28.

Sepulveda L, Syrett S and Lyon F (2011) Population superdiversity and new migrant enterprise: The case of London. Entrepreneurship \& Regional Development 23(7-8): 469-497.

Shane S (2009) Why encouraging more people to become entrepreneurs is bad public policy. Small Business Economics 33(2): 141-149.

Sorenson O (2003) Interdependence and Adaptability: Organizational Learning and the LongTerm Effect of Integration. Management Science 49(4): 446-463.

Støren L A and Wiers-Jenssen J (2010) Foreign Diploma Versus Immigrant Background Determinants of Labour Market Success or Failure? Journal of Studies in International Education 14(1): 29-49.

Sørensen J B (2007) Closure and exposure: Mechanisms in the intergenerational transmission of self-employment. Research in the Sociology of Organizations 25: 83-124. 
Ward R (1986) Ethnic business and economic change: An overview. International Small Business Journal 4(3): 10-12.

Welter F (2011) Contextualizing Entrepreneurship - Conceptual Challenges and Ways Forward. Entrepreneurship Theory and Practice 35(1): 165-184.

Vermeulen H (2010) Segmented assimilation and cross-national comparative research on the integration of immigrants and their children. Ethnic and Racial Studies 33(7): 12141230.

Vershinina N, Barrett R and Meyer M (2011) Forms of capital, intra-ethnic variation and Polish entrepreneurs in Leicester. Work, Employment \& Society 25(1): 101-117.

Wiklund J, Davidsson P and Delmar F (2003) What do they think and feel about growth? An expectancy-value approach to small business managers' attitudes toward growth. Entrepreneurship Theory and Practice 27(3): 247-270.

Wright M and Stigliani I (2013) Entrepreneurship and growth. International Small Business Journal 31(1): 3-22.

Zhou M (1997a) Growing up American: The challenge confronting immigrant children and children of immigrants. Annual Review of Sociology 23(1): 63-95.

Zhou M (1997b) Segmented assimilation: Issues, controversies, and recent research on the new second generation. International Migration Review 31(4): 975-1008. 
Table 1: Measurement period and mean annual growth rates

\begin{tabular}{cccccc}
\hline Year & Observations & Mean & Std. Dev. & Min. & \multicolumn{1}{c}{ Max. } \\
\hline 2005 & 50,002 & $16 \%$ & 2.26 & 0.00 & $270.26 \%$ \\
2006 & 48,301 & $10 \%$ & 0.77 & 0.00 & $81.41 \%$ \\
2007 & 45,456 & $13 \%$ & 2.18 & 0.00 & $317.64 \%$ \\
2008 & 43,249 & $8 \%$ & 1.14 & 0.00 & $141.20 \%$ \\
\hline
\end{tabular}

Table 2: Proportion of firms split according to CEO background during each year

\begin{tabular}{lcccc}
\hline & $\mathbf{2 0 0 5}$ & $\mathbf{2 0 0 6}$ & $\mathbf{2 0 0 7}$ & $\mathbf{2 0 0 8}$ \\
\hline Native CEO & $89.6 \%$ & $89.9 \%$ & $90.3 \%$ & $90.6 \%$ \\
$1^{\text {st }}$ gen. immigrant CEO (OECD) & $5.1 \%$ & $5.0 \%$ & $4.8 \%$ & $4.7 \%$ \\
$1^{\text {st }}$ gen. immigrant CEO (non-OECD) & $2.2 \%$ & $2.2 \%$ & $2.1 \%$ & $2.0 \%$ \\
$2^{\text {nd }}$ gen. immigrant CEO (OECD) & $2.0 \%$ & $2.0 \%$ & $1.9 \%$ & $1.9 \%$ \\
$2^{\text {nd }}$ gen. immigrant CEO (non-OECD) & $1.1 \%$ & $1.0 \%$ & $0.9 \%$ & $0.8 \%$ \\
\hline
\end{tabular}

Table 3: Variable mean and modal values

\begin{tabular}{lrrrr}
\hline Variable & Mean & \multicolumn{1}{c}{ Std. Dev. } & \multicolumn{1}{c}{ Min. } & \multicolumn{1}{c}{ Max. } \\
\hline CEO minority shareholder & 0.10 & 0.30 & 0.00 & 1.00 \\
CEO's partner runs a firm & 0.14 & 0.35 & 0.00 & 1.00 \\
CEO's parents run a firm & 0.12 & 0.33 & 0.00 & 1.00 \\
CEO net wealth & 16.77 & 63.81 & -219.79 & 14631.62 \\
CEO has post-secondary education & 0.12 & 0.32 & 0.00 & 1.00 \\
Female CEO & 0.14 & 0.35 & 0.00 & 1.00 \\
$1^{\text {st }}$ gen. immigrant CEO (OECD) & 0.05 & 0.22 & 0.00 & 1.00 \\
$1^{\text {st }}$ gen. immigrant CEO (non-OECD) & 0.02 & 0.14 & 0.00 & 1.00 \\
$2^{\text {nd }}$ gen. immigrant CEO (OECD) & 0.02 & 0.14 & 0.00 & 1.00 \\
$2^{\text {nd }}$ gen. immigrant CEO (non-OECD) & 0.01 & 0.10 & 0.00 & 1.00 \\
Native CEO & 0.90 & 0.30 & 0.00 & 1.00 \\
Board interlocks & 0.51 & 0.92 & 0.00 & 13.00 \\
Number of board members & 2.68 & 1.07 & 0.00 & 19.00 \\
CEO family size & 7.32 & 3.25 & 0.00 & 28.00 \\
Corporate group & 0.09 & 0.28 & 0.00 & 1.00 \\
Firm relative size & 1.37 & 1.91 & 0.00 & 77.61 \\
Employees' tertiary education (\%) & 7.11 & 19.81 & 0.00 & 100.00 \\
Firm age & 14.60 & 9.00 & 0.00 & 108.00 \\
County share of OECD immigrants & 0.09 & 0.04 & 0.03 & 0.16 \\
County share of non-OECD immigrants & 0.16 & 0.02 & 0.11 & 0.19 \\
Revenue level & $10.9^{\mathrm{e}}+06$ & $20.9^{\mathrm{e}}+06$ & 100 & $9.63 \mathrm{e}+08$ \\
Growth rate & 1.116 & 1.724 & 0.00 & 317.64 \\
\hline Notes: $\mathrm{N}=187,008$ & & & &
\end{tabular}


Table 4: Random effects models on firms' revenue growth, 2005-2008

\begin{tabular}{|c|c|}
\hline & Random \\
\hline CEO minority shareholder & $\begin{array}{l}0.008^{*} \\
(0.004)\end{array}$ \\
\hline CEO's partner runs a firm & $\begin{array}{l}-0.010^{* * *} \\
(0.003)\end{array}$ \\
\hline CEO's parents run a firm & $\begin{array}{l}0.017^{* *} \\
(0.003)\end{array}$ \\
\hline CEO net wealth & $\begin{array}{l}-0.000^{* * *} \\
(0.000)\end{array}$ \\
\hline CEO post-secondary education & $\begin{array}{l}0.011^{* *} \\
(0.004)\end{array}$ \\
\hline Female CEO & $\begin{array}{l}-0.014^{* * *} \\
(0.003)\end{array}$ \\
\hline $1^{\text {st }}$ gen. immigrant CEO $(\mathrm{OECD})$ & $\begin{array}{l}-0.006 \\
(0.005)\end{array}$ \\
\hline $1^{\text {st }}$ gen. immigrant CEO (non-OECD) & $\begin{array}{c}0.008 \\
(0.007)\end{array}$ \\
\hline $2^{\text {nd }}$ gen. immigrant $\mathrm{CEO}(\mathrm{OECD})$ & $\begin{array}{l}0.023^{* *} \\
(0.006)\end{array}$ \\
\hline $2^{\text {nd }}$ gen. immigrant CEO (non-OECD) & $\begin{array}{l}-0.019 \\
(0.010)\end{array}$ \\
\hline Board interlocks & $\begin{array}{l}-0.003^{* *} \\
(0.001)\end{array}$ \\
\hline Number of board members & $\begin{array}{l}0.008^{* *} \\
(0.001)\end{array}$ \\
\hline CEO family size & $\begin{array}{l}0.001^{* *} \\
(0.000)\end{array}$ \\
\hline Corporate group & $\begin{array}{l}-0.021^{* * *} \\
(0.004)\end{array}$ \\
\hline Relative firm size & $\begin{array}{l}0.023^{* *} \\
(0.001)\end{array}$ \\
\hline Employees' tertiary education & $\begin{array}{l}0.000^{* *} \\
(0.000)\end{array}$ \\
\hline Firm age & $\begin{array}{l}-0.003^{* * *} \\
(0.000)\end{array}$ \\
\hline County share of OECD immigrants & $\begin{array}{l}-2.08^{* * *} \\
(0.661)\end{array}$ \\
\hline County share of non-OCED immigrants & $\begin{array}{c}0.84 \\
(0.497)\end{array}$ \\
\hline Constant & $\begin{array}{l}-0.040 \\
(0.158)\end{array}$ \\
\hline Fixed industry effects & Yes \\
\hline Fixed county effects & Yes \\
\hline Year dummies & Yes \\
\hline Firm-year observations & 187,008 \\
\hline$R^{2}$ within & 0.017 \\
\hline$R^{2}$ between & 0.027 \\
\hline$R^{2}$ overall & 0.022 \\
\hline
\end{tabular}

Notes: ${ }^{*} p<0.05,{ }^{* *} p<0.01$. Standard errors clustered on the firm level in parentheses. Six outliers deleted. 
Table 5: Random effects panel models on firms' revenue growth by CEO background, 20052008

\begin{tabular}{|c|c|c|c|c|c|}
\hline & $\begin{array}{l}1^{\text {st }} \text { gen. } \\
\text { immigrant CEO } \\
(\text { OECD })\end{array}$ & $\begin{array}{c}1^{\text {st }} \text { gen. } \\
\text { immigrant CEO } \\
(\text { non-OECD) }\end{array}$ & $\begin{array}{c}2^{\text {nd }} \text { gen. } \\
\text { immigrant CEO } \\
(\text { OECD })\end{array}$ & $\begin{array}{c}2^{\text {nd }} \text { gen. } \\
\text { immigrant CEO } \\
\text { (non-OECD) }\end{array}$ & $\begin{array}{l}\text { Native } \\
\text { CEO }\end{array}$ \\
\hline \multirow[t]{2}{*}{ CEO minority shareholder } & 0.004 & 0.042 & -0.026 & 0.046 & 0.007 \\
\hline & $(0.014)$ & $(0.024)$ & $(0.020)$ & $(0.025)$ & $(0.004)$ \\
\hline \multirow[t]{2}{*}{ CEO's partner runs a firm } & 0.006 & -0.017 & -0.023 & -0.025 & $-0.010 * *$ \\
\hline & $(0.012)$ & $(0.016)$ & $(0.021)$ & $(0.025)$ & $(0.003)$ \\
\hline \multirow[t]{2}{*}{ CEO's parents run a firm } & 0.023 & 0.027 & $0.051 * *$ & -0.170 & $0.017 * *$ \\
\hline & $(0.031)$ & $(0.047)$ & $(0.019)$ & $(0.122)$ & $(0.003)$ \\
\hline \multirow[t]{2}{*}{ CEO net wealth } & -0.000 & $-0.001 *$ & -0.000 & -0.000 & $-0.000 * *$ \\
\hline & $(0.000)$ & $(0.000)$ & $(0.000)$ & $(0.000)$ & $(0.000)$ \\
\hline \multirow[t]{2}{*}{ CEO post-secondary education } & 0.029 & 0.010 & -0.002 & 0.025 & $0.010 *$ \\
\hline & $(0.016)$ & $(0.019)$ & $(0.020)$ & $(0.039)$ & $(0.004)$ \\
\hline \multirow[t]{2}{*}{ Female CEO } & -0.014 & -0.016 & -0.024 & 0.014 & $-0.014 * *$ \\
\hline & $(0.011)$ & $(0.016)$ & $(0.015)$ & $(0.025)$ & $(0.003)$ \\
\hline \multirow[t]{2}{*}{ Board interlocks } & -0.002 & -0.014 & -0.001 & $0.026^{*}$ & -0.003 \\
\hline & $(0.005)$ & $(0.009)$ & $(0.008)$ & $(0.013)$ & $(0.001)$ \\
\hline \multirow[t]{2}{*}{ Number of board members } & $0.010 *$ & 0.008 & $0.020 * *$ & -0.002 & $0.008 * *$ \\
\hline & $(0.005)$ & $(0.008)$ & $(0.007)$ & $(0.009)$ & $(0.001)$ \\
\hline \multirow[t]{2}{*}{ CEO family size } & 0.001 & 0.002 & 0.003 & 0.010 & $0.001 * *$ \\
\hline & $(0.001)$ & $(0.002)$ & $(0.002)$ & $(0.008)$ & $(0.000)$ \\
\hline \multirow{2}{*}{ Corporate group } & $-0.066^{* *}$ & 0.007 & -0.005 & -0.002 & $-0.019 * *$ \\
\hline & $(0.020)$ & $(0.029)$ & $(0.027)$ & $(0.036)$ & $(0.004)$ \\
\hline \multirow[t]{2}{*}{ Relative firm size } & $0.032 * *$ & $0.028 * *$ & $0.023 * *$ & $0.038 * *$ & $0.023 * *$ \\
\hline & $(0.004)$ & $(0.005)$ & $(0.004)$ & $(0.009)$ & $(0.001)$ \\
\hline \multirow[t]{2}{*}{ Employees' tertiary education } & -0.000 & -0.000 & 0.000 & 0.000 & $0.000 * *$ \\
\hline & $(0.000)$ & $(0.000)$ & $(0.000)$ & $(0.001)$ & $(0.000)$ \\
\hline \multirow[t]{2}{*}{ Firm age } & $-0.003 * *$ & $-0.002 *$ & $-0.004 * *$ & -0.001 & $-0.003 * *$ \\
\hline & $(0.001)$ & $(0.001)$ & $(0.001)$ & $(0.001)$ & $(0.000)$ \\
\hline County share of OECD & -6.140 & 1.780 & -0.300 & -3.270 & $-1.980 * *$ \\
\hline immigrants & $(3.408)$ & $(3.666)$ & $(4.963)$ & $(5.384)$ & $(0.697)$ \\
\hline County share of non-OCED & 0.800 & -4.930 & $7.290 *$ & -0.009 & 0.670 \\
\hline Immigrants & $(2.134)$ & $(3.597)$ & $(3.640)$ & $(5.005)$ & $(0.534)$ \\
\hline \multirow[t]{2}{*}{ Constant } & 0.790 & -0.270 & -1.210 & 0.500 & -0.041 \\
\hline & $(0.690)$ & $(0.934)$ & $(1.053)$ & $(1.128)$ & $(0.164)$ \\
\hline Fixed industry effects & Yes & Yes & Yes & Yes & Yes \\
\hline Fixed county effects & Yes & Yes & Yes & Yes & Yes \\
\hline Year dummies & Yes & Yes & Yes & Yes & Yes \\
\hline Firm-year observations & 9,150 & 3,940 & 3,650 & 1,837 & 168,431 \\
\hline$R^{2}$ within & 0.025 & 0.021 & 0.023 & 0.019 & 0.017 \\
\hline$R^{2}$ between & 0.036 & 0.041 & 0.063 & 0.086 & 0.026 \\
\hline$R^{2}$ overall & 0.025 & 0.029 & 0.035 & 0.039 & 0.022 \\
\hline
\end{tabular}

Notes: ${ }^{*} p<0.05,{ }^{* *} p<0.01$. Standard errors clustered on the firm level in parentheses. Six outliers deleted. 
Table 6: Firms' industrial sector according to CEO background

\begin{tabular}{|c|c|c|c|c|c|}
\hline & $\begin{array}{l}\text { Native } \\
\text { CEO }\end{array}$ & $\begin{array}{l}\text { 1st gen. } \\
\text { immigrant } \\
\text { CEO } \\
\text { (OECD) }\end{array}$ & $\begin{array}{l}\text { 1st gen. } \\
\text { immigrant } \\
\text { CEO (non- } \\
\text { OECD) } \\
\end{array}$ & $\begin{array}{l}2^{\text {nd }} \text { gen. } \\
\text { immigrant } \\
\text { CEO } \\
(\mathrm{OECD}) \\
\end{array}$ & $\begin{array}{l}2^{\text {nd }} \text { gen. } \\
\text { immigrant } \\
\text { CEO (non- } \\
\text { OECD) }\end{array}$ \\
\hline \multirow{2}{*}{$\begin{array}{l}\text { Agriculture, forestry, and } \\
\text { fishery }\end{array}$} & 7,017 & 138 & 20 & 84 & 102 \\
\hline & $4.2 \%$ & $1.5 \%$ & $0.5 \%$ & $2.3 \%$ & $5.6 \%$ \\
\hline \multirow[t]{2}{*}{ Manufacturing } & 25,390 & 1,265 & 354 & 456 & 312 \\
\hline & $15.1 \%$ & $13.8 \%$ & $9.0 \%$ & $12.5 \%$ & $17.0 \%$ \\
\hline \multirow{2}{*}{$\begin{array}{l}\text { Energy production, water } \\
\text { Distribution, and waste } \\
\text { management }\end{array}$} & 439 & 14 & 2 & 0 & 5 \\
\hline & $0.3 \%$ & $0.2 \%$ & $0.1 \%$ & $0.0 \%$ & $0.3 \%$ \\
\hline \multirow[t]{2}{*}{ Construction } & 28,727 & 944 & 110 & 469 & 189 \\
\hline & $17.1 \%$ & $10.3 \%$ & $2.8 \%$ & $12.8 \%$ & $10.3 \%$ \\
\hline \multirow{2}{*}{$\begin{array}{l}\text { Trade and } \\
\text { communication }\end{array}$} & 60,838 & 2,542 & 1,208 & 1,188 & 722 \\
\hline & $36.1 \%$ & $27.8 \%$ & $30.7 \%$ & $32.5 \%$ & $39.3 \%$ \\
\hline \multirow{2}{*}{$\begin{array}{l}\text { Financial and business } \\
\text { Services }\end{array}$} & 28,347 & 1,694 & 461 & 773 & 342 \\
\hline & $16.8 \%$ & $18.5 \%$ & $11.7 \%$ & $21.2 \%$ & $18.6 \%$ \\
\hline \multirow{2}{*}{$\begin{array}{l}\text { Research and } \\
\text { development }\end{array}$} & 2,272 & 131 & 58 & 57 & 25 \\
\hline & $1.3 \%$ & $1.4 \%$ & $1.5 \%$ & $1.6 \%$ & $1.4 \%$ \\
\hline \multirow[t]{2}{*}{ Healthcare } & 5,816 & 733 & 279 & 183 & 65 \\
\hline & $3.5 \%$ & $8.0 \%$ & $7.1 \%$ & $5.0 \%$ & $3.5 \%$ \\
\hline \multirow{2}{*}{$\begin{array}{l}\text { Personal and cultural } \\
\text { services }\end{array}$} & 9,578 & 1,686 & 1,447 & 440 & 75 \\
\hline & $5.7 \%$ & $18.4 \%$ & $36.7 \%$ & $12.1 \%$ & $4.1 \%$ \\
\hline Total & 168,431 & 9,150 & 3,940 & 3,650 & 1,837 \\
\hline
\end{tabular}

Notes: Values represent firm year observations. In all, 11 observations lack an industry code and were therefore excluded. 
Table 7: Quantile regressions on firms' revenue growth, 2005-2008

\begin{tabular}{|c|c|c|c|c|c|}
\hline & 10 & 30 & 50 & 70 & 90 \\
\hline \multirow[t]{2}{*}{ CEO minority shareholder } & $-0.025^{* *}$ & $-0.011^{* *}$ & -0.002 & $0.004^{*}$ & $0.022^{* *}$ \\
\hline & $(0.005)$ & $(0.002)$ & $(0.002)$ & $(0.002)$ & $(0.004)$ \\
\hline \multirow[t]{2}{*}{ CEO's partner runs a firm } & 0.003 & 0.001 & $-0.003^{* *}$ & $-0.008^{* *}$ & $-0.019^{* *}$ \\
\hline & $(0.003)$ & $(0.001)$ & $(0.001)$ & $(0.002)$ & $(0.003)$ \\
\hline \multirow[t]{2}{*}{ CEO's parents run a firm } & $0.027^{* *}$ & $0.010^{* *}$ & $0.011^{* *}$ & $0.012^{* *}$ & $0.015^{* *}$ \\
\hline & $(0.004)$ & $(0.002)$ & $(0.001)$ & $(0.002)$ & $(0.004)$ \\
\hline \multirow[t]{2}{*}{ CEO net wealth } & $-0.000^{* *}$ & $-0.000^{* *}$ & $-0.000^{* *}$ & $-0.000^{*}$ & $-0.000^{*}$ \\
\hline & $(0.000)$ & $(0.000)$ & $(0.000)$ & $(0.000)$ & $(0.000)$ \\
\hline \multirow[t]{2}{*}{ CEO post-secondary education } & -0.007 & -0.004 & 0.002 & $0.005^{* *}$ & $0.023^{* *}$ \\
\hline & $(0.006)$ & $(0.002)$ & $(0.002)$ & $(0.002)$ & $(0.004)$ \\
\hline \multirow[t]{2}{*}{ Female CEO } & $0.018^{* *}$ & -0.001 & $-0.012^{* *}$ & $-0.025^{* *}$ & $-0.047^{* *}$ \\
\hline & $(0.005)$ & $(0.001)$ & $(0.001)$ & $(0.001)$ & $(0.003)$ \\
\hline \multirow[t]{2}{*}{$1^{\text {st }}$ gen. immigrant CEO (OECD) } & $-0.019^{* *}$ & $-0.006^{*}$ & $-0.007^{* *}$ & $-0.006^{*}$ & 0.000 \\
\hline & $(0.007)$ & $(0.003)$ & $(0.002)$ & $(0.003)$ & $(0.005)$ \\
\hline \multirow[t]{2}{*}{$1^{\text {st }}$ gen. immigrant CEO (non-OECD) } & $-0.016^{*}$ & -0.003 & -0.003 & 0.002 & 0.016 \\
\hline & $(0.008)$ & $(0.003)$ & $(0.004)$ & $(0.005)$ & (0.009) \\
\hline \multirow[t]{2}{*}{$2^{\text {nd }}$ gen. immigrant CEO (OECD) } & 0.012 & $0.010^{*}$ & $0.014^{* *}$ & $0.019^{* *}$ & $0.036^{* *}$ \\
\hline & $(0.006)$ & $(0.004)$ & $(0.004)$ & $(0.005)$ & $(0.012)$ \\
\hline \multirow[t]{2}{*}{$2^{\text {nd }}$ gen. immigrant CEO (non-OECD) } & $-0.050^{* *}$ & $-0.017^{*}$ & $-0.012^{* *}$ & $-0.015^{* *}$ & -0.009 \\
\hline & $(0.011)$ & $(0.007)$ & $(0.004)$ & $(0.005)$ & $(0.013)$ \\
\hline \multirow[t]{2}{*}{ Board interlocks } & $-0.014^{* *}$ & $-0.003^{* *}$ & -0.000 & $0.003^{* *}$ & $0.012^{* *}$ \\
\hline & $(0.002)$ & $(0.001)$ & $(0.001)$ & $(0.001)$ & $(0.002)$ \\
\hline \multirow[t]{2}{*}{ Number of board members } & $0.011^{* *}$ & $0.004^{* *}$ & $0.003^{* *}$ & $0.002^{* *}$ & 0.001 \\
\hline & $(0.001)$ & $(0.001)$ & $(0.000)$ & $(0.001)$ & $(0.001)$ \\
\hline \multirow[t]{2}{*}{ CEO family size } & $0.003^{* *}$ & $0.001^{* *}$ & $0.000^{* *}$ & $0.000^{* *}$ & -0.000 \\
\hline & $(0.000)$ & $(0.000)$ & $(0.000)$ & $(0.000)$ & $(0.000)$ \\
\hline \multirow[t]{2}{*}{ Corporate group } & $-0.043^{* *}$ & -0.004 & 0.003 & $0.008^{* *}$ & $0.033^{* *}$ \\
\hline & $(0.008)$ & $(0.002)$ & $(0.002)$ & $(0.003)$ & $(0.005)$ \\
\hline \multirow[t]{2}{*}{ Relative firm size } & $0.020^{* *}$ & $0.013^{* *}$ & $0.011^{* *}$ & $0.011^{* *}$ & $0.010^{* *}$ \\
\hline & $(0.000)$ & $(0.000)$ & $(0.000)$ & $(0.000)$ & $(0.001)$ \\
\hline \multirow[t]{2}{*}{ Employees' tertiary education } & -0.000 & $0.000^{*}$ & $0.000^{* *}$ & $0.000^{* *}$ & $0.001^{* *}$ \\
\hline & $(0.000)$ & $(0.000)$ & $(0.000)$ & $(0.000)$ & $(0.000)$ \\
\hline \multirow[t]{2}{*}{ Firm age } & $0.001^{* *}$ & $-0.001^{* *}$ & $-0.0013^{* *}$ & $-0.002^{* *}$ & $-0.005^{* *}$ \\
\hline & $(0.000)$ & $(0.000)$ & $(0.000)$ & $(0.000)$ & $(0.000)$ \\
\hline \multirow[t]{2}{*}{ County share of OECD immigrants } & -1.790 & $-1.580^{* *}$ & $-1.540^{* *}$ & $-1.520^{* *}$ & -1.480 \\
\hline & $(1.171)$ & $(0.506)$ & $(0.286)$ & $(0.499)$ & (1.015) \\
\hline \multirow[t]{2}{*}{ County share non-OCED immigrants } & 2.020 & $0.790^{*}$ & 0.360 & -0.260 & -0.980 \\
\hline & $(1.069)$ & $(0.317)$ & $(0.253)$ & $(0.288)$ & $(0.642)$ \\
\hline \multirow[t]{2}{*}{ Constant } & $-0.64^{*}$ & -0.052 & 0.130 & $0.310^{* *}$ & $0.540^{* * *}$ \\
\hline & $(0.254)$ & $(0.240)$ & $(0.153)$ & $(0.110)$ & $(0.170)$ \\
\hline Fixed industry effects & Yes & Yes & Yes & Yes & Yes \\
\hline Fixed county effects & Yes & Yes & Yes & Yes & Yes \\
\hline Annual dummies & Yes & Yes & Yes & Yes & Yes \\
\hline Firm-year observations & 37,402 & 37,401 & 37,402 & 37,401 & 37,402 \\
\hline$R^{2}$ & 0.026 & 0.012 & 0.012 & 0.026 & 0.048 \\
\hline
\end{tabular}

Notes: ${ }^{*} p<0.05,{ }^{* *} p<0.01$. Standard errors clustered on the firm level in parentheses. Six outliers deleted. 
Figure 1: Level of revenue by CEO background, 2005-2008

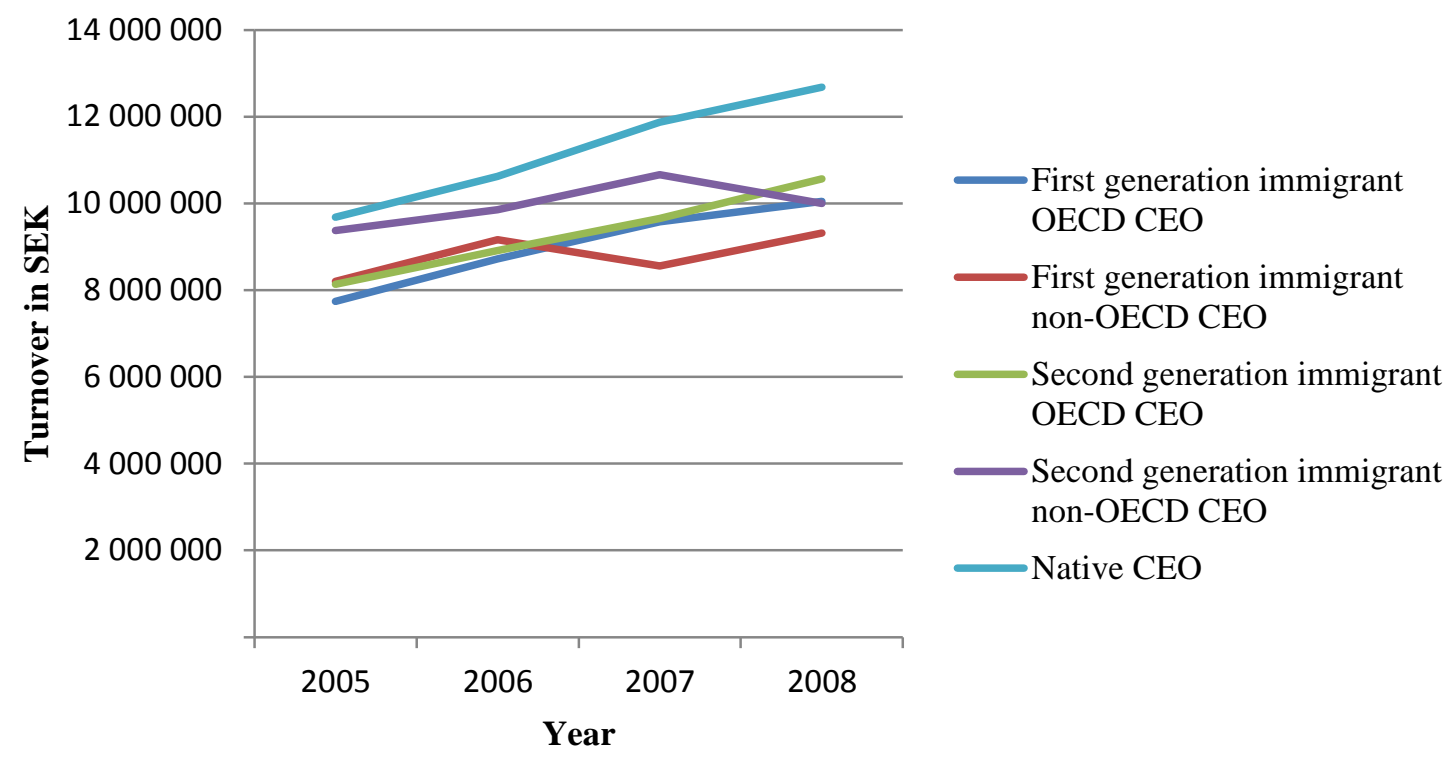

Notes: The y-axis is measured in Swedish Krona (SEK). 10 SEK = roughly $€ 1$ during the period of investigation.

Figure 2: Year-to-year growth in revenue, 2005-2008
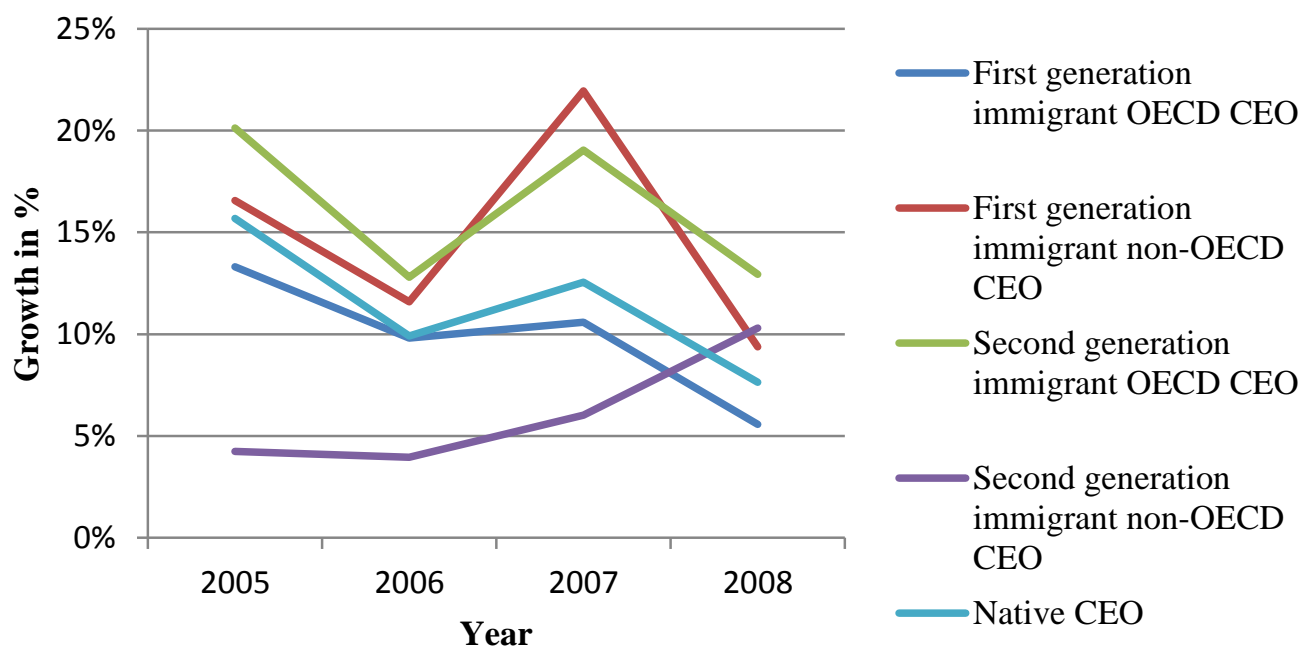

Notes: The y-axis is measured in Swedish Krona (SEK). 10 SEK = roughly $€ 1$ during the period of investigation. 